\title{
Analyze Factors That Affect Carbon Emission Disclosure (Case Study in Non-Financial Firms Listed on Indonesia Stock Exchange in 2014-2016)
}

\author{
Cantika Anindya Hapsari ${ }^{1}$ and Andrian Budi Prasetyo*2 \\ ${ }^{1,2}$ Accounting Department of Faculty of Economics and Business, Universitas Diponegoro, Indonesia
}

\section{ARTICLE INFO}

Article History:

Received January $12^{\text {th }}, 2020$

Accepted March $5^{\text {th }}, 2020$

Available July $30^{\text {th }}, 2020$

\section{Keywords:}

carbon emission disclosure; profitability; leverage; corporate governance

\begin{abstract}
The purpose of this study is to find out what factors can have an impact on the disclosure of carbon emissions in non-financial companies listed on the Indonesia Stock Exchange that issues sustainability reports. The variables to be tested in this study are independent variables consisting of industry type, company size, profitability, leverage and corporate governance, as well as the dependent variable which is the disclosure of carbon emissions. Based on secondary data and purposive sampling methods, as many as 57 non-financial companies listed on the Indonesia Stock Exchange that published sustainability reports for 2014-2016 were obtained as research samples. Multiple linear regression was used as the analysis model in this study. Based on the test results, it was found that the variables that had a significant influence on the level of carbon emissions disclosure were industry type, company size and leverage, while the profitability and corporate governance variables were found to have no significant effect. From the results of the study, it can be concluded that of the 57 companies that became the study sample, there were 36 companies that revealed above average carbon emissions. This shows that companies which are included in emission-intensive industries disclose better carbon emissions.
\end{abstract}

(C) 2020 Published by UNNES. This is an open access article under the CC BY license (http://creativecommons.org/licenses/by/4.0/)

\section{INTRODUCTION}

The issue of global warming in various countries becomes important for the political and business environment. This is based on the myriad challenges posed by the threat of global warming create strong response to these challenges that come from environmental, business and political leaders. One of which is the necessity of the entities in understanding and communicating their contribution to global warming. On the other hand, public becomes more sensitive to pollution generated by entities (Siregar \& Deswanto, 2018). Increased sensitivity of the community, based on increasing awareness of the scope of the problems that can be caused by global warming which can lead to more environmentally responsible decisions.

One form of corporate responsibility towards stakeholders is social and environmental responsibility. Stakeholders in this case are people or groups that can influence and be influenced by company policies, decisions and activities. Consideration of the company

\footnotetext{
* E-mail: Jl. Prof. Soedharto SH Tembalang, Semarang 50239, _Address: andrianbp1589@live.undip.ac.id
}

in social and environmental responsibility disclosure in annual report is to help decision-making for stakeholders and sustainability measures for managers (Deegan, 2004). Another consideration is to get legitimacy from the stakeholders, then avoid threats such as the risk of a decline in the company's reputation, increased operating costs, reduced demand, legal process, fines and penalties to be paid by the company (Berthelot \& Robert 2011). Carbon emissions disclosure is one form of social and environmental responsibility practice undertaken by the company, which is part of the social and environmental responsibility disclosure.

Companies in Indonesia have chosen to be careful in carrying out their business activities. Participation in the United Nations Framework Convention on Climate Change (UNFCCC) is one of the parts of Indonesia's commitment in reducing greenhouse gas emissions. This done by the ratification of the first period of the Kyoto Protocol in 2004 which ended in 2012 and ratified the second period of the Kyoto Protocol in 2014 will expire in 2020. Follow-up efforts to stabilize the concentration of greenhouse gases (GHGs) in the atmosphere at a level that does not endanger the Earth's climate system, Indonesia ratifies Law No. 6 of 1994 and 
through Law No. 32 of 2009 regarding Environmental Protection and Management (BAPPENAS, 2010). At the Presidential Decree No. 61 In 2011 discussing the National Action Plan for GHG Emission Reduction explained that efforts to reduce it were also carried out by businesses (Zulaikha, 2016). One form of Indonesia's commitment to reduce greenhouse gas emissions is demonstrated through the issuance of Presidential Regulation No. 71 of 2011 concerning the implementation of GHG inventories (Suhardi \& Purwanto, 2015). The existence of such regulations provides an chance to find out how Indonesia's companies react to the changes of environment.

This research was conducted on the basis of the gap phenomenon, namely that the low number of companies that disclose carbon emission disclosure in Indonesia. This gap phenomenon occurs because it is still very rare for companies in Indonesia to disclose carbon emissions and this disclosure is still voluntary (Cahya, 2016). As stated by Choi et al. (2013) that disclosure of carbon emissions is made as a reaction to environmental pressures, so if companies in Indonesia care about the environment, they will tend to make disclosure of carbon emissions. In addition, this study was also motivated because of the research gap or the inconsistency of the results that occurred in previous studies. Zhang et al. (2012); Le Luo (2013); Irwhantoko \& Basuki (2016) found that leverage has an influence on carbon emissions disclosure, whereas Choi et al. (2013) found no significant effect between leverage and carbon emissions disclosure. Related to the effect between profitability and carbon emissions disclosure, Zhang et al. (2012); Choi et al. (2013); Irwhantoko \& Basuki (2016) found that profitability affected the carbon emissions disclosure while the results of Le Luo (2013) profitability did not affect the carbon emissions disclosure.

This study refers to the research of Choi et al. (2013) with the difference that lies in determining the criteria of corporate governance, objects, and research samples. This research contributes to the development of theory in Indonesia, especially in carbon emission disclosure and as a consideration of stakeholders in decision making, considering the transparency of carbon emissions information is an important thing for stakeholders as well as government considerations or policies related to carbon emissions reduction. The objective of this study is to examine whether industry type, company size, profitability leverage and corporate governance can affect carbon emissions disclosure in Indonesia.

This research is based on the legitimacy theory that explains about social contracts that occur between companies and communities around the company. Legitimacy can be interpreted as: " a generalized perception or assumption that the actions of an entity are desirable, proper, or appropriate within some socially constructed system of norms, values, beliefs, and definitions" (Suchman, 1995). Based on the legitimacy theory, voluntary disclosure can be tool to enforce social contracts. Companies can use voluntary environmental disclosure to gain legitimacy by reducing social and political pressure Choi et al. (2013). Based on the opinion of Fernando \&
Lawrence (2014), the legitimacy theory does not only pay attention to the interests of investors but needs to be considered related to the rights of the wider community, which if they fail to comply with the social contract, then they will be subject to sanctions by the public. In this case, the manifestation of response to the pressure which is to disclose carbon emissions.

Regarding to the legitimacy theory, companies legitimize their activities in response to institutional, political and social pressures through disclosure of information regarding social and environmental aspects (Dowling \& Pfeffer, 1975). Companies that operate in emission-intensive industries are generally companies that get public attention and get pressure from the government because their operating activities have the potential to intersect with broad interests. The government may pay attention to social programs created by companies and pressure companies to disclose information as fully as possible about their social responsibilities. It's because one of the government's commitments is to contribute to fighting climate change and reducing global temperatures (Irwhantoko \& Basuki, 2016). The government pressures companies that produce more emissions to make disclosures, so that the government can monitor the activities generated by the company. It can be concluded that companies that disclose more information on carbon emission are companies operating in emission-intensive industries compared to companies operating in non-emission intensive industries. Research conducted by Zhang et al. (2012) and Choi et al. (2013) found that industrial types influence carbon disclosure. Based on the description, the following hypothesis can be formulated:

\section{H1: Industrial Type has a positive influence on car- bon emission disclosure.}

Relates to the theory of legitimacy, the company tried to justify its existence with the legitimacy of its activities as a form of concern for external pressure (Dowling \& Pfeffer, 1975). Cowen et al. (1987) stated that companies with the larger size would have investors who might pay attention to social programs made by companies and pressure companies to disseminate information about social responsibility, so that company activities get recognition from the community around the company. If the company does not care about the environment, investors are reluctant to invest in the company because the company in the long term cannot avoid the big costs due to the demands of the community around the company. According to Fang et al. (2011), companies will increase the disclosure of their information as part of a business strategy to build a good corporate social image because of the assumption that large companies face greater social dan political pressure than smaller companies. Furthermore, companies use a good social image to get the trust of investors and potential investors's trust who will invest in the company. To sum up, the higher size of the company the higher carbon emission disclosure. Research conducted by Borghei-Ghomi \& Leung (2013); Choi et al. (2013) found that company size po- 
sitively affect the carbon emission disclosure. Based on the description, the suggested hypothesis is:

\section{H2 : Company Size has a positive influence on car- bon emission disclosure.}

Relates to the theory of legitimacy, the company tried to justify its existence with the legitimacy of its activities as a form of concern for external pressure (Dowling \& Pfeffer, 1975). Pressure is given by investors so that companies care about environmental issues by encouraging companies to make carbon emissions disclosures more responsible. If the company cares about environmental problems, shows good corporate reputation, corporate relations with important parties such as banks and government are also good where this can lead to company profits, investors and prospective investors will also consider and respond positively in the form of investment decisions on companies that care about the environment. According to Pradini \& Kiswara (2013) the pressure will be given by investors to companies that have high profitability because companies with high profits will be more likely to get the spotlight and have additional finance to make disclosures. Therefore, the higher value of profitability indicates that the company has good financial performance. In order to reduce the pressure coming from investors, companies with better financial performance have the financial ability to add carbon emission reduction strategies to one of their business strategies. It can be concluded that the higher profitability of the company, the higher carbon emission disclosure will be carried out as evidence of corporate accountability to investors and ensures that company's business activities are in line with social norms and values in the community (Nugroho \& Yulianto, 2015). The research conducted by Le Luo (2013) and Choi et al. (2013) found that profitability positively related to higher carbon emission disclosure. Based on the description, the suggested hypothesis is:

\section{H3: Profitability has a positive influence on carbon emission disclosure.}

Relates to the theory of legitimacy, the company seeks to find the legality of its business activities due to external pressure (O'Donovan, 2002). Creditors will likely put pressure on companies to prioritize interest payments and repay obligations rather than making voluntary disclosures Choi et al. (2013). This is considered to only increase the financial burden. If the company does disclosure of carbon emissions, creditors will feel that the company will have difficulty in paying off obligations and paying interest because the costs that should be paid to creditors will be used to make disclosures. Creditors want the company to repay obligations and interest payments in a timely manner so in the future it will not harm the creditors. On the other hand, companies with high leverage have a tendency to not conducting voluntary disclosures such as carbon emission disclosure which will add extra cost to the company in order to save costs Le Luo (2013). The presumed direction between the degree of leverage and the disclosure of carbon energy is negative, this is due to the limited ability of company to implement the carbon reduction and disclosure strategies caused by the liabilities that are greater than debt and interest payments. The higher of company's leverage, the lower of carbon emissions disclosure. The research conducted by Choi et al. (2013) and Le Luo (2013) found that leverage affected carbon disclosure. Based on the description, the suggested hypothesis is:

\section{H4 : Leverage has a negative influence on carbon emission disclosure.}

Regarding to the theory of legitimacy, voluntary disclosure can be used as a tool to enforce social contracts and reduce social and political pressure (Choi et al., 2013). Pressure is given by investors so that companies make high carbon emissions disclosures, because the activities and conditions of the company must be reported and known by investors. Investors have a role to press companies to disclose corporate social activities while companies will try to satisfy the stakeholders's need in this case investors, including information disclosure needs of corporate social activities. Corporate governance is very important for a company related to transparent disclosure (Cohen et al., 2004). So the pressure from investors will be given to companies that have good corporate governance, because investors feel that the disclosure will be more transparent and complete than companies with poor corporate governance. Companies with good corporate governance will minimize pressure from investors who pay attention to company activities by disclosing their social responsibilities, one of which relates to carbon emissions. Puspitasari \& Darsono (2009) states that with pressure from investors, companies with good corporate governance will express their carbon emissions as a form of legitimacy and increase the company's social image. As shown above, the better the corporate governance, the more demands from investors want to know about the company's activities in full, so more information on carbon emissions disclosed by the company. Choi et al. (2013) found that corporate governance influenced the carbon emissions disclosure. Based on the description, the suggested hypothesis is:

\section{H5 : Corporate Governance has a positive influence on carbon emission disclosure.}

\section{RESEARCH METHODS}

This study uses the disclosure of carbon emission as dependent variable. In this study, the disclosure of carbon emission was measured using the disclosure index Choi et al. (2013) which will be assessed by comparing the number of disclosure scores made by companies with the number of disclosure scores required in the disclosure index of Choi et al. (2013).

Industrial type, company size, profitability, leverage, and corporate governance are independent variables which is thought to affecting the variable disclosure of carbon emissions. Identification of industrial types using dummy variables. Score 1 is given if the company is one of an emissions intensive industry member that 
covers the energy, transportation, materials and utilities industries in accordance with the Global Industry Classification Standards, while the score is 0 otherwise. Company size in this research measured by the total assets which are converted into natural logarithms. Profitability of this study uses Return on Assets (ROA), which is the comparison of current year's earnings with total assets. To measure the leverage, this study calculates the ratio of the total liabilities borne by the company and total assets. Corporate governance is measured using disclosure index taken from the Decision of the Chairperson of BAPEPAM and Financial Institutions in Regulation XK6 Number: Kep-134 / BL / 2006 and General Guidelines for the Implementation of Good Corporate Governance in Indonesia concerning the submission of a brief description of implementation of corporate governance in annual report.

Non-financial companies listed on the IDX during 2014-2016 used as population in this study. The sampling method uses purposive sampling with the criteria the companies that issue annual reports and sustainability reports consecutively in 2014-2016 and nonfinancial companies that disclose their carbon emissions implicitly or explicitly (at least disclose one item from the available index). The analytical method used to test internal factors for carbon emission disclosure is multiple linear regression analysis. Regression models used to test hypotheses are shown by equation 1 :

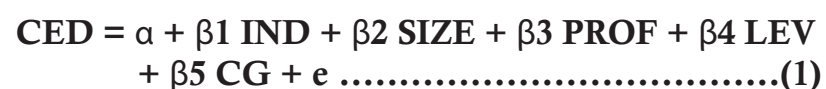

Information :

CED = Carbon Emission Disclosure

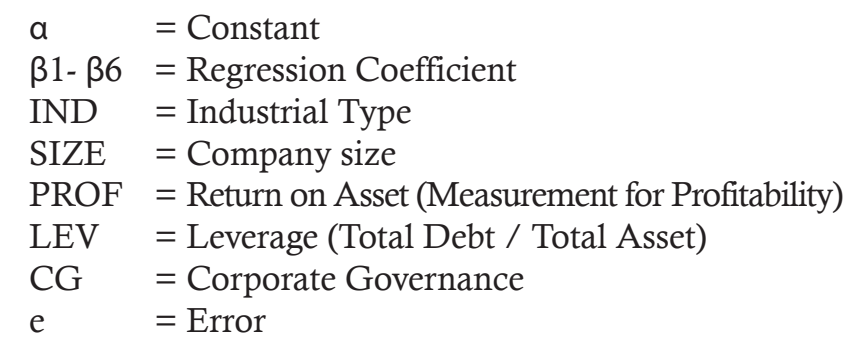

\section{RESULTS AND DISCUSSION}

The object of this research is non-financial companies listed on the IDX during_2014-2016. Purposive sampling method is used to determine the research sample. A total of 57 companies were selected as research samples according to the criteria based on this method. An explanation of sampling is shown in Table 1.

Descriptive statistics which include minimum, maximum average and standard deviation value of each variables in this study are shown in table 2 . Table 3 shows descriptive statistics of the industrial type dummy variable frequency.

Carbon emission disclosure (CED) variables are determined using the CED index developed in the research of Choi et al. (2013) which consists of 18 items disclosure, if the company discloses all existing items, the maximum value is 18 or $100 \%$. Based on the table 3 , the minimum value of this variable is 0.11 and the maximum value is 0.89 . This variable has average value of 0.5049 and the standard deviation value of 0.23670 or $23.67 \%$.

Dummy variable to measure industry type (IND) has 0 as lowest value and the highest value of 1 . Table 3 shows that from a total of 57 companies there were

Table 1. Research Object

\begin{tabular}{lcccc}
\hline \multicolumn{1}{c}{ Description } & \multicolumn{3}{c}{ Period } \\
\cline { 2 - 5 } & 2014 & 2015 & 2016 & Total \\
\hline $\begin{array}{l}\text { Non-financial companies listed on IDX for 2014 until 2016 } \\
\begin{array}{l}\text { Companies that were eliminated because they did not issue Sustainability Re- } \\
\text { ports in a row for 2014 until 2016 }\end{array}\end{array}$ & 425 & 440 & 452 & 1318 \\
$\begin{array}{l}\text { Non-financial companies that implicitly and explicitly do not disclose their } \\
\text { carbon emissions }\end{array}$ & $(25)$ & $(408)$ & $(1186)$ \\
Research Object & $(25)$ & $(25)$ & $(75)$ \\
\hline
\end{tabular}

Table 2. Descriptive Statistics

\begin{tabular}{ccccc}
\hline & Minimum & Maximum & Mean & Standard Deviation \\
\hline SIZE & 21.63 & 26.29 & 24.1161 & 0.93749 \\
Profitability & -0.12 & 0.18 & 0.0514 & 0.05492 \\
Leverage & 0.13 & 0.78 & 0.5244 & 0.15791 \\
CG & 0.51 & 0.94 & 0.7581 & 0.13896 \\
CED & 0.11 & 0.89 & 0.5049 & 0.23670 \\
\hline
\end{tabular}

Source: Secondary data processed. 2019

Table 3. Dummy Variable Frequency

\begin{tabular}{crr}
\hline Valid & Frequency & \multicolumn{1}{c}{ Percent } \\
\hline 0 & 21 & 36.8 \\
1 & 36 & 63.2 \\
\hline Total & 57 & 100.0 \\
\hline \multicolumn{2}{l}{ Source: Secondary data processed, 2019}
\end{tabular}


36 companies or $63.2 \%$ of the total samples which included emission-intensive industry which had sensitive characteristics to occurrence environmental damage. The remaining 21 companies or $36.8 \%$ of the total sample included emission non-intesive industry, which had characteristics that are less sensitive to environmental damage.

The variable company size (SIZE) is measured using $\ln$ total assets. The greater value, meaning the company is getting bigger because it has more total assets (ln total assets). Based on the table 2, its obtained 21.63 as minimum value and 26.29 as maximum value. The average SIZE value is 24.1161 and the SIZE standard deviation value is 0.93749 .

Profitability variable (PROF) is measured by looking at the company's return on assets (ROA). Based on table 2 , PROF variable produce -0.12 as minimum value and 0.18 as a maximum value. The average value of PROF is 0.0514 and the standard deviation value is 0.05492 .

Leverage variable (LEV) is obtained by dividing the amount of company debt by the number of company assets. Table 2 shows that this variable produces 0.13 as minimum value and 0.78 as maximum value. The average value for LEV is 0.5244 and the standard deviation of LEV is 0.15791.

The corporate governance variable (CG) is determined using the corporate governance index based on the Decree of the Chairperson of BAPEPAM and Financial Institutions as well as the General Guidelines for the Implementation of Indonesian Good Corporate Governance which consists of 103 disclosure items, if the company discloses all items, the maximum value is 103 or $100 \%$. Based on table 2, this CG variables obtained 0.51 as minimum value and 0.94 as maximum value. The mean value of CG is 0.7581 and the CG standard deviation value is 0.13896 or $13.886 \%$.

The research model needs to be tested first to identify whether the model is free from problems of normality, multicollinearity, autocorrelation and heteroscedasticity before conducting the regression analysis. This test is carried out using the classic assumption test. The conclusion of the test is that the data used in the study are normal, and free from multicollinearity, heteroscedasticity and autocorrelation problems.

The results of hypothesis testing are obtained from the test that shown in table 4 . The t test or partial test is conducted to determine whether the dependent variable is influenced by individual independent variables. If the research variable has sig. $<0.05$, it indicates a significant influence on the dependent variable.

Table 4. Hypothesis Test

\begin{tabular}{lccc}
\hline \multicolumn{1}{c}{ Model } & $\mathrm{B}$ & $\mathrm{T}$ & Sig. \\
\hline (Constant) & -0.341 & -0.475 & 0.637 \\
IND & 0.158 & 2.525 & 0.015 \\
SIZE & 0.059 & 2.107 & 0.040 \\
Profitability & 0.316 & 0.452 & 0.653 \\
Leverage & -0.682 & -2.826 & 0.007 \\
CG & -0.437 & -1.972 & 0.054 \\
\hline \multicolumn{2}{c}{ Source: Secondary data processed, 2019 }
\end{tabular}


has a negative relation to carbon emissions disclosure. The company obtains additional capital from creditors so that creditors have the power to influence company management in decision making. Creditors can influence and pressure a company if the company dwells too much on social activities. This is because creditors expect their interests to take precedence over social activities. So the company will try to reveal carbon emissions to a minimum to avoid pressure from creditors.

\section{The Effect of Corporate Governance on Carbon Emission Disclosure}

The results of the fifth hypothesis test indicate that corporate governance does not have a significant relationship to carbon emission disclosure. This research is in accordance with that found by Faisal et al. (2012) which states that corporate governance has no impact on influencing disclosure of carbon emissions. The company gives less attention to public shareholders who are generally small investors who own shares below just $5 \%$. Share ownership, one of which is retail shareholders (small scale), where they are lacking in carrying out the functions of monitoring and do not pressure companies related to CSR activities. This will not affect the broader disclosure of carbon emission because in fact many investors rely more on technical analysis tools than fundamental analysis tools. In addition, companies with good corporate governance will choose not to disclose information that will disrupt the value of the company, causing loss of investor confidence.

\section{CONCLUSION}

The results showed that the disclosure of carbon emissions was positively influenced by industry type and company size while leverage was negatively related to the disclosure of carbon emissions of non-financial companies listed on the IDX during 2014-2016. In addition, the results of this study also show that profitability and corporate governance do not affect the disclosure of carbon emissions.

The limitations in this study that there are $65.3 \%$ of other factors apart from the independent variables namely industrial type, company size, profitability, leverage, and corporate governance that can predict the dependent variable, namely carbon emission disclosure.

For further research development, the suggestion given based on conclusions and limitations is that future research can consider to add other variables that have not been used in this study that can affect the dependent variable. Some other independent variables that can be associated with carbon emission disclosure are media exposure and environmental performance.

\section{REFERENCES}

Bappenas. (2010). Rencana Aksi Nasional Penurunan Emisi Gas Rumah Kaca (Ran Grk).

Berthelot, S., \& Robert, A. M. (2011). Climate change disclosures: An examination of Canadian oil and gas firms. Issues in Social and Environmental Accounting, 5(1/2), 106-123. https://doi.org/10.22164/isea.v5i2.61.
Borghei-Ghomi, Z., \& Leung, P. (2013). An Empirical Analysis Of The Determinants Of Greenhouse Gas Voluntary Disclosure In Australia. Accounting And Finance Research, 2(1), 110-127.

Cahya, B. T. (2016). Carbon Emission Disclosure: Ditinjau Dari Media Exposure, Kinerja Lingkungan Dan Karakteristk Perusahaan Go Publik Berbasis Syariah Di Indonesia. Nizham, 5(2), 170-188.

Choi, B.B., Lee, D., \& Psaros, J. (2013). An Analysis Of Australian Company Carbon Emission Disclosures. Pacific Accounting Review, 25(1), 58-79.

Cohen, J. R., Krishnamoorthy, G., \& Wright, A. (2004). The corporate governance mosaic and financial reporting quality. Journal of accounting literature, 87-152. https:// doi.org/Doi 10.1016/S0266-3538(98)00151-1.

Cowen, S. S., Ferreri, L. B., \& Parker, L. D. (1987). The impact of corporate characteristics on social responsibility disclosure: A typology and frequency-based analysis. Accounting, Organizations and society, 12(2), 111-122.

Deegan, C. (2004). Environmental Disclosures And Share Prices - A Discussion About Efforts To Study This Relationship. Accounting Forum, 28(1), 87-97.

Dowling, J., \& Pfeffer, J. (1975). Organizational Legitimacy: Social Values And Organizational Behavior Between The Organizations Seek To Establish Congruence. The Accounting Review, 18(1), 122-136.

Faisal, F., Tower, G., \& Rusmin, R. (2012). Legitimising corporate sustainability reporting throughout the world. Australasian Accounting, Business and Finance Journal, 6(2), 19-34.

Fang, J. Y., Zhu, J. L., Wang, S. P., Yue, C., \& Shen, H. H. (2011). Global Warming, Human-Induced Carbon Emissions, And Their Uncertainties. Journal of Accounting, Auditing \& Finance, 54(10), 1458-1468.

Fernando, S., \& Lawrence, S. (2014). A Theoretical Framework For Csr Practices: Integrating Legitimacy Theory, Stakeholder Theory And Institutional Theory. Journal Of Theoretical Accounting Research, 10(1), 149-178.

Global Reporting Initiative. (2016). GRI 305: Emissions 2016.

Irwhantoko, I., \& Basuki, B. (2016). Carbon Emission Disclosure: Studi Pada Perusahaan Manufaktur Indonesia. Jurnal Akuntansi Dan Keuangan, 18(2), 92-104.

Le Luo, Q. T., \& Y.-C. L. (2013). Comparison Of Propensity For Carbon Disclosure Between Developing And Developed Countries. Accounting Research Journal, 26(1), 6-34.

Nugroho, M. N., \& Yulianto, A. (2015). Pengaruh Profitabilitas Dan Mekanisme Corporate Governance Terhadap Pengungkapan Csr Perusahaan Terdaftar JII 20112013. Accounting Analysis Journal, 4(1), 1-12.

O'donovan, G. (2002). Environmental Disclosures In The Annual Report: Extending The Applicability And Predictive Power Of Legitimacy Theory. Accounting, Auditing \& Accountability Journal, 15(3), 344-371.

Pradini, H. S., \& Kiswara, E. (2013). The Analysis of Information Content towards Greenhouse Gas Emissions Disclosure in Indonesia Companies. Diponegoro Journal of Accounting, 2 (2): 1-12. https://ejournal3.undip.ac.id/ index.php/accounting/article/view/3317.

Puspitasari, A. D. \& Darsono (2009). Faktor-Faktor yang Mempengaruhi Pengungkapan Corporate Social Responsibility (CSR) Pada Laporan Tahunan Perusahaan di Indonesia. Diponegoro Jurnal Of Accounting, 4(2), 155-157.

Siregar, S. V., \& Deswanto, R. B. (2018). Association Between Environmental Disclosures With Financial Performance, Environmental Performance, And Firm Value. 
Social Responsibility Journal, 4(1), 180-193.

Suchman, M. C. (1995). Managing Legitimacy: Strategic And Institutional Approache. Journal of Accounting, Auditing \& Finance, 20(3), 571-610.

Suhardi, R.P. \& Purwanto, A. (2015). Analisis Faktor - Faktor Yang Mempengaruhi Pengungkapan Emisi Karbon Di Indonesia. Diponegoro Jurnal Of Accounting, 4(1), 1-13.

Zhang, S., Mcnicholas, P., \& Birt, J. (2012). Australian Corporate Responses To Climate Change: The Carbon Disclosure Project. Accounting Research Journal, 28(1), $1-33$.

Zulaikha, A. P. (2016). Analisis Pengungkapan Emisi Gas Rumah Kaca. Diponegoro Jurnal Of Accounting, 13(2), 155-175. 